\title{
Phyllometry and carpometry, chemical and functional characterization of fruits of Sorbus domestica L. (service tree) selections
}

\author{
Maria Claudia Piagnani ${ }^{\mathrm{a}, *}$, Claudia Debellini ${ }^{\mathrm{a}}$ and Roberto LoScalzo ${ }^{\mathrm{b}}$ \\ a Department of Plant Production, University of Milan, Milan, Italy \\ ${ }^{\mathrm{b}}$ CRA-IAA, Milan, Italy
}

Received 16 March 2011; accepted 20 June 2011

\begin{abstract}
Service tree (Sorbus domestica L.) belongs to a large genus of plants, that in the past characterized the agricultural landscape of large areas of Europe. In the light of recent acquisitions regarding nutraceutical and functional properties of service fruits in allied Sorbus species, our work aimed at the morphological description, evaluation of fruit quality and functionalnutraceutical properties of the same accessions selected for timber, in order to identify double aptitude plants.

Morphological and chemical differences among plant selections were found particularly for titratable acidity and red colour of the skin: bletting contributed to mitigate such differences. Chromatograms obtained by reversed-phase HPLC analysis indicated that the phenolic compounds present in the matrix may be assimilated to three main classes of compounds: gallic acid, its derivative and polymeric tannins. Acids and flavonols were present in much lower quantities this indicating that the main phenolic compounds nature of our service fruit selections were hydrolysable tannins. A linear and positive correlation was found between the two methods, DPPH-EPR and CAB, used to assay antioxidant capacity this indicating that easy to manage DPPH-EPR assay may be used for substrates that are high in phenols as the case of service fruits. Our original hypothesis of wide variability among trees was finally confirmed by discriminant analysis which admitted most of the recorded variables, and showed each plant selection as a case in itself.
\end{abstract}

Keywords: Phenolic content, fruit extracts, flavonoids, DPPH-EPR scavenging spectra, crocin bleaching assay

\section{Introduction}

Service tree (Sorbus domestica L.) is one of the less known and used fruit tree species with a low level of domestication [8]. Service tree belongs to a large genus of plants, that in the past characterized the agricultural landscape of large areas of Europe.

Despite the currently limited diffusion of this species, service tree exhibits many attractive features as well as being highly valuable for its timber. In particular as an indigenous wild fruit species is part of a natural ecosystem and its conservation and promotion contribute to ecosystem improvement [22]; furthermore it is adapted to withstand moisture stress and has a potential for forestation of degraded areas. Unfortunately, neglect, ageing and the felling of old individuals are threatening this species. In past rural culture, the tree was used as medicinal plant and its fruits played a major role in fall and winter providing a valuable stock of vitamins and natural sugars. In contrast to the wide range of attractive and tasty fruits currently on the market, service tree's small, strongly astringent fruits are only edible after over ripening and are somewhat difficult to appreciate for the modern consumer. Recent

*Corresponding author: Maria Claudia Piagnani, PhD, Department of Plant Production, University of Milan, via Celoria 2, 20133 Milan, Italy. Tel.: +39 0250316564; Fax: +39 0250316553; E-mail: claudia.piagnani@unimi.it. 
work however, indicates potential for this fruit as a nutraceutical product with high antiradical activity and possible benefits in reducing complications of diabetes mellitus [15]. Characterization of both in situ and ex situ collections have been initiated in several E.U. Countries [17-19]. Nevertheless, these programs, with few exceptions [3], did not consider at all the use of fruit. The objective of this research was the identification of criteria for selecting good quality fruit accessions as part of a wider project partially funded by Lombardy Region aimed at the characterization and production of selected plus $S$. domestica trees for timber. In this context and in the light of recent acquisitions regarding nutraceutical and functional properties of service fruits in allied Sorbus species [13], our work aimed at the morphological description, evaluation of fruit quality and functional-nutraceutical properties of the same accessions selected for timber. Considering the long production cycle for obtaining marketable wood (starting from 25-30 years), the identification of double aptitude plants could furnish a middle income to the producer.

Service tree has been propagated by seed for many centuries and, given the likely close allogamy, quite wide variability is expected for different plant traits including fruit quality.

Our results provide a basis for more detailed varietal characterisation of Sorbus tree.

\section{Material and methods}

\subsection{Plant material}

A seedling orchard of $S$. torminalis was established in 2001 at the Experimental Farm "Cascina Baciocca" (Cornaredo-Milano) of the University of Milan. Trees were spaced at $6.0 \mathrm{~m} \times 6.0 \mathrm{~m}$ in a medium fertility loose soil. For fruit evaluation we considered 14 seedlings of Sorbus domestica L. coming from a single isolated plant located in Bologna Appennines (Central Italy) and named 'Tosca' which had previously been selected for timber production attitude (vigorous, fast growing, upright habit). Such trees were planted in two adjacent rows. Phyllometry (measurement of parameters in leaves) was carried out; Sorbus domestica leaves are composite, 11-21 leaflets, and pinnate. Fruits, randomly selected from the crown, were picked by hand about one week after veraison stage for two consecutive years. The analysis to determine the characteristics of "physiologically ripe" (ripe) fruits were carried out within 24 hours after harvest while those on bletted fruits were performed after two weeks in dark room at $20^{\circ} \mathrm{C}$ and $60 \%$ Relative Humidity. Six trees were sampled to perform bletted fruits analysis, because of their higher productivity. Trees were subjected to formative pruning to shape a potential timber tree, consequently, some crowns were not so expanded to bring enough fruits to perform the analysis. In Table 1 are shown the analysis performed for each plant selection.

\subsection{Morphological analysis}

\subsubsection{Phyllometry}

Three healthy and fully expanded leaves were sampled from uniformly sun-exposed area from the middle part of crown of each tree (Table 1), at the end of June. Leaflets were recorded for: lamina length (LL), lamina width (LW), leaflet number and Leaf Index, a parameter to indicate the surface occupied by leaves, was also calculated as the following: $\mathrm{LI}=\mathrm{LL} * \mathrm{LW} *$ leaflet number.

\subsubsection{Carpometry}

A representative sample of fruits (100 fruits/tree) was chosen for the carpometric analysis. Fruit weight was assessed by an electronic scale (accuracy $=0.1 \mathrm{~g}$ Mettler PM 4600).

Polar and equatorial diameters were measured by an electronic gauge, Kanon EMS-6). Fruit shape was assessed both with length-to-width ratio and by comparison with a pomological card [2]. Seeds were also counted.

\subsubsection{Skin colour}

Fruit skin colour was measured with a Minolta Chroma Meter (Model CR-200. Minolta Camera Co. Ltd.-Ku Osaka, Japan) as CIE (Commission Internationale de I'Eclairage, translated as the International Commission of Illumination, 1976) $\mathrm{L}^{*} \mathrm{a}^{*}$ and $\mathrm{b}^{*}$. Chroma and Hue angle were then calculated. 
Table 1

Leaves and fruits analytical evaluation scheme

\begin{tabular}{|c|c|c|c|c|c|}
\hline \multirow{2}{*}{$\begin{array}{l}\text { Plant } \\
\text { selection }\end{array}$} & \multicolumn{2}{|c|}{ Leaves } & \multicolumn{3}{|c|}{ Fruits } \\
\hline & Phyllometry & Carpometry & $\begin{array}{l}\text { Chemical } \\
\text { analysis }\end{array}$ & $\begin{array}{c}\text { Polyphenols antioxidant } \\
\text { assays and DA* }\end{array}$ & Bletted \\
\hline 9.04 & $\mathrm{X}$ & $\mathrm{X}$ & $\mathrm{X}$ & $X$ & \\
\hline 9.05 & $X$ & $\mathrm{X}$ & $X$ & $X$ & $\mathrm{X}$ \\
\hline 10.01 & $X$ & $X$ & $X$ & $X$ & $\mathrm{X}$ \\
\hline 10.02 & $X$ & $X$ & $\mathrm{X}$ & $\mathrm{X}$ & \\
\hline 10.03 & $\mathrm{X}$ & $\mathrm{X}$ & $X$ & $X$ & \\
\hline 10.04 & $\mathrm{X}$ & $\mathrm{X}$ & $\mathrm{X}$ & $\mathrm{X}$ & $\mathrm{X}$ \\
\hline 10.05 & $\mathrm{X}$ & $X$ & $\mathrm{X}$ & & \\
\hline 10.06 & $\mathrm{X}$ & $\mathrm{X}$ & $\mathrm{X}$ & & \\
\hline 10.08 & $\mathrm{X}$ & $\mathrm{X}$ & $\mathrm{X}$ & & \\
\hline 10.11 & $\mathrm{X}$ & $X$ & $X$ & $X$ & $X$ \\
\hline 10.12 & $\mathrm{X}$ & $\mathrm{X}$ & $\mathrm{X}$ & & \\
\hline 10.14 & $\mathrm{X}$ & $\mathrm{X}$ & $\mathrm{X}$ & $\mathrm{X}$ & $\mathrm{X}$ \\
\hline 10.15 & $X$ & $\mathrm{X}$ & $X$ & $X$ & \\
\hline 10.16 & $\mathrm{X}$ & $\mathrm{X}$ & $\mathrm{X}$ & $X$ & $\mathrm{X}$ \\
\hline
\end{tabular}

$* \mathrm{DA}=$ discriminant analysis

\subsection{Chemical analysis}

Three biological replicates composed of five fruits each, representative of each tree production were considered, and stored at $-80^{\circ} \mathrm{C}$ before the analysis. Chemical analysis were performed for two years on ripe fruits only. The edible portion of frozen fruits was manually separated from the seeds using a stainless steel knife and triturated in a domestic mixer to form a homogeneous mass.

\subsubsection{Titratable acidity}

In service berry 70 to $90 \%$ of the acidity is represented by malic acid. The remaining amount is primarily represented by quinic and succinic acid. Other acids such as citric and ascorbic are detected in trace amounts [5]. Consequently, total acid content was expressed as $\mathrm{mEq}$ malic acid per $100 \mathrm{~g}$ fresh weight of fruit.

\subsubsection{Soluble solids content}

Total soluble solids content (TSS) was determined with RFM 81 (Multiscale automatic refractometer) and expressed as ${ }^{\circ} \mathrm{Bx}$ on juice, obtained after fruit squeezing with a manual squeezer.

\subsubsection{Fruit extracts}

Fruit extract was done by mixing in a screw capped centrifuge tube, $5 \mathrm{~g}$ minced fruit flesh at $0-1^{\circ} \mathrm{C}$ and $20 \mathrm{ml}$ cold $0.01 \mathrm{M} \mathrm{HCl}$. The mixture was manually and vortex shaken and centrifuged for 20 minutes at $20000 \times \mathrm{g}$ at $2-4^{\circ} \mathrm{C}$. The extract was filtered and poured into vials. The residue remaining in the test tube was dried with paper towels and resuspended in $10 \mathrm{ml}$ of cold $\mathrm{EtOH} / 0.01 \mathrm{M} \mathrm{HCl}(9: 1)$. The solutions were centrifuged as above and the filtered supernatant poured into vials. Samples were stored at $-20^{\circ} \mathrm{C}$. Three extracts were made for each plant selection starting from three biological replicates (paragraph 3 ).

\subsubsection{Estimation of the phenolic content by the Folin-Ciocalteu test}

Total concentration of the phenols in the extracts was determined according to the Folin-Ciocalteu [21] on ten plant selections. $0.2 \mathrm{ml}$ extract, $2 \mathrm{ml}$ distilled water and $0.5 \mathrm{ml}$ Folin-Ciocalteu reagent were added in a vial and manually mixed. $1 \mathrm{ml}$ of aqueous sodium carbonate (20\%) was added and the mixture was incubated at room temperature in the dark for 2 hours. The vial content was then transferred to a $10 \mathrm{~mm}$ cuvette and read at $730 \mathrm{~nm}$ using a double beam 
spectrophotometer (Pye-Unicam mod 4000). The total phenol concentration was calculated from the calibration curve using chlorogenic acid as an external standard and the results were expressed as $\mathrm{mg}$ of chlorogenic acid equivalent (CAE)/100 g FW.

\subsubsection{Flavonoids}

Total flavonoids were assayed only on extracts from ripe fruits. For bletted fruits the absorbance resulted too low and it was not possible to reach a good spectrophotometric reading.

Zou et al. [23] method was used: $0.5 \mathrm{ml}$ extract $2 \mathrm{ml}$ of distilled water and $0.15 \mathrm{ml}$ of $5 \% \mathrm{NaNO}_{2}$ were stirred manually and $0.15 \mathrm{ml}$ of $\mathrm{AlCl}_{3}(10 \%)$ and $2 \mathrm{ml}$ of $\mathrm{NaOH} 4 \%$ were added in succession. After 15 min reaction time the solution was transferred into a cuvette for spectrophotometric reading at $510 \mathrm{~nm}$. The results were expressed as $\mathrm{mg}$ of catechin equivalents $(\mathrm{CE}) / 100 \mathrm{~g} \mathrm{FW}$.

\subsubsection{Phenol hydrolysis}

To better assess antioxidant composition of the matrix a method for polyphenols hydrolysis was developed, following the method used by Olszewska [13], with some modifications: $1 \mathrm{ml}$ extract was treated into close vial at $80^{\circ} \mathrm{C}$ for 40 minutes with $1 \mathrm{ml} \mathrm{HCl} 6 \mathrm{~N}$ and $1 \mathrm{ml} \mathrm{EtOH}$ absolute. In such way hydrolyzed samples $(\mathrm{H})$ were obtained to compare with the non hydrolyzed (not treated) ones $(\mathrm{NH})$.

\subsubsection{Single phenolic analysis}

The analysis for the identification of individual phenols in service fruit extracts was carried out by RP-HPLC-DAD. The HPLC-DAD chromatographic separation was conducted on reversed phase column ODS-3, length $250 \mathrm{~mm}$ and $4 \mathrm{~mm}$ internal diameter column with isocratic elution of $10 \%$ acetonitrile $5 \%$ acetic acid and $85 \%$ bi-distilled water at a flow rate of $0.7 \mathrm{ml} / \mathrm{min}$, column temperature of $40^{\circ} \mathrm{C}$ and injection volume of $40 \mu \mathrm{l}$. The system used was JASCO HPLC equipped with auto sampler and diode detector UV-VIS interfaced to a personal computer for data acquisition (software Borwin-PDA, JASCO version 2).

The quantified compounds were gallic acid (retention time 6.1 minutes) and another one which was tentatively identified as a gallic acid derivative (retention time 4.8 minutes). The gallic acid derivative was identified by its chromatographic behaviour similar to gallic acid for its strong increase after acid hydrolysis and its UV spectrum, peaking at $281.5 \mathrm{~nm}$. The quantification of both compounds $\mathrm{s}$ was given as gallic acid equivalents (GAE/100 $\mathrm{g} \mathrm{fw})$.

\subsection{Functional characterization}

The antioxidant capacity of all extracts was determined, on ten plant selections (Table 1), by using two methods: the DPPH (1,1-diphenyl-2-picryl-hydrazyl) test according to the rationale of Brand-Williams et al. [6] and the "crocin bleaching assay" (CBA) as referred by MacDonald-Wicks et al. [12].

\subsubsection{DPPH-EPR scavenging method}

Different dilutions of fruit extracts were prepared by dissolving the samples in EtOH/0.01 $\mathrm{M} \mathrm{HCl}(9: 1)$. An aliquot of $100 \mu \mathrm{l} 1$ of diluted sample was added to $0.3 \mathrm{ml}$ of $\mathrm{MeOH}$ and $100 \mu 1 \mathrm{lof} \mathrm{DPPH}$ solution in EtOH (0.5 mM) and EPR spectra were recorded after introducing the resulting solution into a capillary at $25^{\circ} \mathrm{C}$ using a Miniscope MS 200 Magnettech, Berlin spectrometer operating at $9440 \mathrm{Ghz}$. The reaction time was settled at 1 minute.

The following instrument settings were used: modulation amplitude $2000 \mathrm{mG}$, field center $3350 \mathrm{G}$, microwave power $7 \mathrm{~dB}$, scan range $50 \mathrm{G}$, scan time $45 \mathrm{sec}$. Spectra were recorded and analysed using Miniscope MS 200 software (Magnettech, Berlin). The amplitude of the DPPH spectra main band was acquired for each sample and plotted against the data of spectra obtained in the absence of antioxidants, considered as blank, calibrating the system in the presence of Trolox (a water soluble analogue of vitamin E) solution at known concentration.

The results were expressed as the Trolox equivalents (TE, mg/100 $\mathrm{g}$ of sample FW).

\subsubsection{CBA scavenging method}

CBA assay is based on the crocin bleaching as a result of its oxidation by a source of free radicals obtained by thermal decomposition of AAPH [2,20-azo-bis(2-aminopropane)dihydrochloride]. CBA method was used both for 
hydrolyzed (H) and not-hydrolyzed (NH) samples. Different extract concentrations were prepared: as regarding ripe fruit extract the reaction mixture contained $10 \mu \mathrm{l}$ of sample, $1640 \mu \mathrm{l}$ of $0.1 \mathrm{M}$ phosphate buffer (pH 7.4), $200 \mu \mathrm{l}$ crocin $(1 \mathrm{mM})$ and $300 \mu \mathrm{l}$ of $70 \mathrm{mM}$ AAPH. For all the other samples (bletted) a solution of $25 \mu 1$ of sample with $1625 \mu$ l of phosphate buffer was prepared. The reactions started with the introduction of the source of peroxyl radicals produced by thermal degradation of AAPH dissolved in $0.1 \mathrm{M}$ phosphate buffer (pH 7.4), in a water bath at $37^{\circ} \mathrm{C}$. The bleaching rate of crocin was elapsed for $60 \mathrm{~min}$ at $37^{\circ} \mathrm{C}$ and the correspondent decrease of absorbance was read after this time at $440 \mathrm{~nm}$ against a 'blank' (same reagents without crocin). As before stated for DPPH, the system was calibrated with Trolox solutions at known concentrations, so the results were expressed as Trolox equivalents (TE, mg/100 g of sample FW).

\subsubsection{Statistical analysis}

Data were analysed by one-way ANOVA and the differences contrasted using the Tuckey's test. Correlations were evaluated according to Pearson's two-tailed test. Discriminant analysis was also applied. Statistical analysis was performed at 5\% level using SPSS 18.0 package for Windows by SPSS inc.

\section{Results}

\subsection{Morphological analysis}

\subsubsection{Phyllometry}

As shown in Table 2, plant selection '9.04' recorded the highest values in terms of both lamina length $(7.8 \mathrm{~cm})$ and width $(2.6 \mathrm{~cm})$ at the opposite selection ' 9.05 ' showed the lowest values, $4.4 \mathrm{~cm}$ and $1.4 \mathrm{~cm}$ respectively. The most roundish leaflets belong to selection ' 10.15 ' the most oval to ' 10.01 '. Leaflets numbers varied from 11.7 (selection '10.04') and 17.0 (selection '9.05'). Leaf Index, ranged from 119.0 (selection '10.01') and 328.0 (selection '10.11').

\subsubsection{Carpometry}

As from Table 3 "physiologically ripe" (ripe) fruit weight was ranging from 6.9 (plant selection '10.06') to 16.0 (plant selection '10.02'). It may be noted (Table 3 ) that bletting involved fruit weight reduction, between 1.5 and

Table 2

Phyllometry of plant selections leaflets: lamina length (LL); lamina width (LW); lamina width/lamina length ratio(W/L), number of leaflets per leaf (Leaflets/Leaf) and LI $=\mathrm{LL} * \mathrm{LW}^{*}$ leaflet number

\begin{tabular}{lcclcc}
\hline Plant selection & LL $(\mathrm{cm})$ & LW $(\mathrm{cm})$ & W/L & Leaflets/leaf $(n)$ & LI \\
\hline 9.04 & $7.8 \mathrm{~h}$ & $2.6 \mathrm{e}$ & $0.33 \mathrm{abcd}$ & $13.7 \mathrm{abc}$ & $280.6 \mathrm{e}$ \\
9.05 & $4.4 \mathrm{a}$ & $1.4 \mathrm{a}$ & $0.33 \mathrm{ab}$ & $17.0 \mathrm{~d}$ & $106.5 \mathrm{a}$ \\
10.01 & $5.3 \mathrm{bc}$ & $1.6 \mathrm{a}$ & $0.30 \mathrm{a}$ & $12.0 \mathrm{abc}$ & $124.0 \mathrm{ab}$ \\
10.02 & $6.2 \mathrm{ef}$ & $2.2 \mathrm{c}$ & $0.36 \mathrm{bcde}$ & $13.0 \mathrm{abc}$ & $181.5 \mathrm{abcd}$ \\
10.03 & $4.7 \mathrm{ab}$ & $1.6 \mathrm{a}$ & $0.34 \mathrm{abcd}$ & $13.7 \mathrm{abc}$ & $110.9 \mathrm{a}$ \\
10.04 & $5.1 \mathrm{bc}$ & $1.9 \mathrm{~b}$ & $0.38 \mathrm{de}$ & $11.7 \mathrm{a}$ & $111.2 \mathrm{a}$ \\
10.05 & $6.9 \mathrm{fg}$ & $2.5 \mathrm{de}$ & $0.38 \mathrm{de}$ & $13.7 \mathrm{abc}$ & $247.2 \mathrm{cde}$ \\
10.06 & $6.1 \mathrm{de}$ & $2.1 \mathrm{bc}$ & $0.34 \mathrm{abcd}$ & $13.3 \mathrm{abc}$ & $171.7 \mathrm{abcd}$ \\
10.08 & $5.2 \mathrm{bc}$ & $1.9 \mathrm{~b}$ & $0.37 \mathrm{bcd}$ & $13.0 \mathrm{abc}$ & $130.9 \mathrm{ab}$ \\
10.11 & $7.6 \mathrm{hg}$ & $2.5 \mathrm{e}$ & $0.34 \mathrm{abcd}$ & $13.7 \mathrm{abc}$ & $263.5 \mathrm{de}$ \\
10.12 & $5.8 \mathrm{cde}$ & $2.3 \mathrm{~cd}$ & $0.40 \mathrm{ef}$ & $13.7 \mathrm{abc}$ & $182.9 \mathrm{abcd}$ \\
10.14 & $6.5 \mathrm{ef}$ & $2.0 \mathrm{bc}$ & $0.32 \mathrm{ab}$ & $15.7 \mathrm{~cd}$ & $206.7 \mathrm{bcde}$ \\
10.15 & $5.4 \mathrm{bcd}$ & $2.2 \mathrm{c}$ & $0.43 \mathrm{f}$ & $13.0 \mathrm{abc}$ & $157.5 \mathrm{abc}$ \\
10.16 & $5.4 \mathrm{bcd}$ & $1.6 \mathrm{a}$ & $0.30 \mathrm{a}$ & $14.3 \mathrm{abc}$ & $125.6 \mathrm{ab}$ \\
mean & $5.9 \pm 0.3$ & $2.1 \pm 0.1$ & $0.35 \pm 0.0$ & $13.7 \pm 0.4$ & $171.5 \pm 15.8$ \\
\hline
\end{tabular}

Means with the same letter are not different according to the Tukey's test at 0.05 level, $35 \leq n \leq 61$. 
Table 3

Carpometry of physiologically ripe (A) and bletted (B) fruits: weight, polar and equatorial diameters, polar and equatorial diameters ratio and seed number. (B) Weight reduction percentage in comparison with ripe fruits

\begin{tabular}{|c|c|c|c|c|c|}
\hline Plant selection & Weight $(\mathrm{g})$ & Polar $\emptyset(\mathrm{mm})$ & Equatorial $\emptyset(\mathrm{mm})$ & Polar/equatorial & Seed $(n)$ \\
\hline 9.04 & $14.9 \mathrm{fg}$ & $29.1 d$ & 29.7cde & 1.98de & $7.4 \mathrm{e}$ \\
\hline 9.05 & $9.0 \mathrm{~b}$ & $25.0 \mathrm{bc}$ & $26.2 b$ & $0.97 \mathrm{de}$ & $4.7 \mathrm{ab}$ \\
\hline 10.01 & $12.9 \mathrm{def}$ & $26.4 \mathrm{bc}$ & $28.5 \mathrm{~cd}$ & $0.93 \mathrm{~cd}$ & 5.1abcd \\
\hline 10.02 & $16.0 \mathrm{~g}$ & $26.7 \mathrm{bcd}$ & $31.2 \mathrm{e}$ & $0.86 \mathrm{ab}$ & $6.4 \mathrm{e}$ \\
\hline 10.03 & $13.5 \mathrm{defg}$ & $28.6 \mathrm{~d}$ & $28.9 \mathrm{cde}$ & $0.99 \mathrm{e}$ & 4.9abc \\
\hline 10.04 & $10.9 \mathrm{c}$ & $23.5 \mathrm{a}$ & $28.3 \mathrm{~cd}$ & $0.83 \mathrm{a}$ & $6.5 \mathrm{e}$ \\
\hline 10.05 & 13.0def & $25.0 \mathrm{abc}$ & 29.1cde & $0.86 \mathrm{ab}$ & $6.7 \mathrm{e}$ \\
\hline 10.06 & $6.9 \mathrm{a}$ & $27.2 \mathrm{~cd}$ & $22.0 \mathrm{a}$ & $1.24 \mathrm{~g}$ & $4.5 \mathrm{a}$ \\
\hline 10.08 & $14.9 \mathrm{defg}$ & $27.2 \mathrm{~cd}$ & $31.1 \mathrm{de}$ & $0.88 \mathrm{abc}$ & $6.1 \mathrm{de}$ \\
\hline 10.11 & $14.0 \mathrm{efg}$ & $27.1 \mathrm{~cd}$ & $29.8 \mathrm{de}$ & $0.91 \mathrm{bc}$ & $5.6 \mathrm{cde}$ \\
\hline 10.12 & 14.9defg & $24.9 \mathrm{abc}$ & 31.0de & $0.81 \mathrm{a}$ & $6.8 \mathrm{e}$ \\
\hline 10.14 & 12.6de & $28.4 d$ & $27.6 \mathrm{bc}$ & $1.03 \mathrm{f}$ & $4.4 \mathrm{a}$ \\
\hline 10.15 & $12.1 \mathrm{~d}$ & $24.8 \mathrm{ab}$ & $28.2 \mathrm{bcd}$ & $0.88 \mathrm{abc}$ & $6.1 \mathrm{de}$ \\
\hline 10.16 & 13.3defg & $24.9 \mathrm{ab}$ & $28.9 \mathrm{cde}$ & $0.86 a b$ & $5.6 \mathrm{bcde}$ \\
\hline Mean & $12.8 \pm 0.7$ & $26.3 \pm 04$ & $28.6 \pm 0.6$ & $0.9 \pm 0.03$ & $5.8 \pm 0.2$ \\
\hline
\end{tabular}

Means with the same letter are not different according to the Tukey's test at 0.05 level, $n=14$.

\begin{tabular}{lccccc} 
Bletted $(\mathrm{B})$ & & & \\
\hline Plant selection & Weight $(\mathrm{g})$ & Polar $\emptyset(\mathrm{mm})$ & Equatorial $\emptyset(\mathrm{mm})$ & Polar/equatorial & Weight reduction $(\%)$ \\
\hline 9.05 & $8.8 \mathrm{a}$ & $22.5 \mathrm{~b}$ & $24.2 \mathrm{~b}$ & $0.9 \mathrm{a}$ & $1.5 \mathrm{a}$ \\
10.01 & $9.1 \mathrm{a}$ & $22.3 \mathrm{~b}$ & $21.2 \mathrm{a}$ & $1.0 \mathrm{~b}$ & $29.2 \mathrm{~b}$ \\
10.04 & $8.2 \mathrm{a}$ & $19.3 \mathrm{a}$ & $22.9 \mathrm{ab}$ & $0.8 \mathrm{a}$ & $24.8 \mathrm{~b}$ \\
10.11 & $12.8 \mathrm{~b}$ & $24.4 \mathrm{~b}$ & $27.3 \mathrm{c}$ & $0.9 \mathrm{a}$ & $8.6 \mathrm{a}$ \\
10.14 & $9.9 \mathrm{a}$ & $24.1 \mathrm{~b}$ & $22.7 \mathrm{ab}$ & $1.1 \mathrm{~b}$ & $21.4 \mathrm{~b}$ \\
10.16 & $9.5 \mathrm{ab}$ & nd & nd & nd & $28.6 \mathrm{~b}$ \\
Mean \pm & $9.7 \pm 0.7$ & $18.8 \pm 0.9$ & $19.7 \pm 1.0$ & $0.8 \pm 0.0$ & $19.0 \pm 4.5$ \\
\hline
\end{tabular}

Means with the same letter are not different according to the Tukey's test at 0.05 level, $n=11$; nd $=$ not determined.

$29.2 \%$, and bletted fruits showed lower variability in term of weight comparing to ripe fruits. Differences in the equatorial and polar diameters among plants was smaller than differences in weight. The ratio of the two diameters showed that the fruits harvested from plants '10.02', '10.04', '10.05', '10.08', '10.11', '10.12', '10.15' and '10.16' have a more flattened shape while the fruits harvested from plants '9.04', '9.05', '10.01', '10.03', '10.06' and '10.14' have an oval shape. The number of seeds contained in the mesocarp showed another difference among plants as seed mean number ranged from 4.4 to 7.4 .

Regarding bletted fruits they recorded a reduction in both polar and equatorial diameter (14\% and $17 \%$ average, respectively, data in Table 3 ).

\subsubsection{Skin colour}

In Table 4 skin colour parameters are shown. $\mathrm{L}^{*}$ represents bright to dark as $\mathrm{L}^{*}$ values increase from 0 (absolute black) to100 (absolute white); in our case these values vary from 33.3 to 56.3 dividing plants into 4 groups of significance and fruits of accession ' 10.02 ' showing the most luminous colour (highest $\mathrm{L}^{*}$ parameter). $\mathrm{a}^{*}$ represents green to red as $\mathrm{a}^{*}$ values increase from negative to positive (ranging from -60 to +60 ): according to this parameter plants were divided into four significance groups and the reddest fruits were those of selection ' 10.06 ' $\left(a^{*}=24.0\right)$. $b^{*}$ represents blue to yellow as $b^{*}$ values increase from negative to positive: $b^{*}$ is ranging from 11.9 (selection ' 10.15 ') 
Table 4

Skin color of ripe fruits (A) and plant selection average of bletted fruits (B)

\begin{tabular}{|c|c|c|c|c|c|c|c|c|c|c|}
\hline A) Plant selection & L red & a red & b red & Red dye & Hue red & L green & a green & $\mathrm{b}$ green & Green dye & Hue green \\
\hline 9.04 & 38.3abcde & $17.8 \mathrm{abc}$ & $15.85 \mathrm{abc}$ & $0.8 \mathrm{a}$ & $224.5 \mathrm{a}$ & $53.3 \mathrm{ab}$ & $-1.8 \mathrm{~d}$ & $26.1 \mathrm{ab}$ & $-0.4 \mathrm{a}$ & $156.3 \mathrm{a}$ \\
\hline 9.05 & 38.0abcd & $11.7 \mathrm{a}$ & $16.27 \mathrm{abc}$ & $0.7 \mathrm{a}$ & $220.0 \mathrm{a}$ & $51.1 \mathrm{a}$ & $-5.5 \mathrm{~cd}$ & $27.8 \mathrm{ab}$ & $-0.4 \mathrm{a}$ & $154.9 \mathrm{a}$ \\
\hline 10.01 & $35.4 \mathrm{abc}$ & $21.4 \mathrm{c}$ & $13.72 \mathrm{ab}$ & $0.6 \mathrm{a}$ & $214.3 \mathrm{a}$ & 59.0abcd & $-5.0 \mathrm{~cd}$ & $35.5 \mathrm{bcd}$ & $-0.7 \mathrm{a}$ & $138.0 \mathrm{a}$ \\
\hline 10.02 & $56.3 \mathrm{~g}$ & $12.2 \mathrm{ab}$ & $31.58 \mathrm{e}$ & $0.4 \mathrm{a}$ & $203.3 \mathrm{a}$ & $67.8 \mathrm{~d}$ & $-9.9 \mathrm{abc}$ & $39.1 \mathrm{~cd}$ & $-1.3 \mathrm{a}$ & $104.3 \mathrm{a}$ \\
\hline 10.03 & $47.0 \mathrm{f}$ & $11.5 \mathrm{ab}$ & $26.18 \mathrm{de}$ & $0.3 \mathrm{a}$ & $199.8 \mathrm{a}$ & $61.4 \mathrm{bcd}$ & $-12.8 \mathrm{a}$ & $41.8 \mathrm{~d}$ & $-1.3 \mathrm{a}$ & $107.0 \mathrm{a}$ \\
\hline 10.04 & $44.3 \mathrm{ef}$ & $11.5 \mathrm{a}$ & $22.57 \mathrm{cde}$ & $0.5 \mathrm{a}$ & $210.0 \mathrm{a}$ & $65.1 \mathrm{~d}$ & $-11.4 \mathrm{ab}$ & $43.2 \mathrm{~d}$ & $-1.3 \mathrm{a}$ & $104.8 \mathrm{a}$ \\
\hline 10.05 & $35.3 \mathrm{ab}$ & $15.1 \mathrm{abc}$ & $13.26 \mathrm{ab}$ & $0.7 \mathrm{a}$ & $223.2 \mathrm{a}$ & $49.8 \mathrm{a}$ & $0.0 \mathrm{~d}$ & $24.9 \mathrm{ab}$ & $-0.1 \mathrm{a}$ & $172.1 \mathrm{a}$ \\
\hline 10.06 & $37.7 \mathrm{abcd}$ & $24.0 \mathrm{c}$ & $16.34 \mathrm{abc}$ & $0.6 \mathrm{a}$ & $213.7 \mathrm{a}$ & $65.7 \mathrm{~cd}$ & $-10.1 \mathrm{abc}$ & $44.8 \mathrm{~d}$ & $-1.2 \mathrm{a}$ & $113.8 \mathrm{a}$ \\
\hline 10.08 & 42.2abcdef & $22.5 b c$ & 20.60abcd & $0.7 \mathrm{a}$ & $221.9 \mathrm{a}$ & $64.7 \mathrm{bcd}$ & $-10.6 a b c$ & $43.9 \mathrm{~d}$ & $-1.3 \mathrm{a}$ & $103.5 \mathrm{a}$ \\
\hline 10.11 & $39.5 \mathrm{bcde}$ & $16.8 \mathrm{abc}$ & $18.12 \mathrm{abc}$ & $0.7 \mathrm{a}$ & $222.6 \mathrm{a}$ & $57.5 \mathrm{abc}$ & $-3.2 \mathrm{~d}$ & $32.2 \mathrm{abc}$ & $-0.6 \mathrm{a}$ & $144.4 \mathrm{a}$ \\
\hline 10.12 & 43.5abcdef & $23.2 \mathrm{bc}$ & 22.00abcde & $0.8 \mathrm{a}$ & $223.3 \mathrm{a}$ & $65.9 \mathrm{bcd}$ & $-8.4 \mathrm{abcd}$ & $40.3 \mathrm{bcd}$ & $-1.4 \mathrm{a}$ & $101.7 \mathrm{a}$ \\
\hline 10.14 & 41.7bde & $11.6 \mathrm{a}$ & $20.14 b c$ & $0.7 \mathrm{a}$ & $218.8 \mathrm{a}$ & $53.7 \mathrm{ab}$ & $-7.9 \mathrm{bcd}$ & $31.6 a b c$ & $-0.7 \mathrm{a}$ & $141.8 \mathrm{a}$ \\
\hline 10.15 & $33.3 \mathrm{a}$ & $16.0 \mathrm{abc}$ & $11.90 \mathrm{a}$ & $0.7 \mathrm{a}$ & $222.0 \mathrm{a}$ & $49.9 \mathrm{a}$ & $0.1 \mathrm{~d}$ & $23.5 \mathrm{a}$ & $-0.2 \mathrm{a}$ & $166.3 \mathrm{a}$ \\
\hline \multirow[t]{2}{*}{10.16} & 40.3abcde & 16.3abc & $17.05 \mathrm{abc}$ & $0.8 \mathrm{a}$ & $227.3 \mathrm{a}$ & $56.1 \mathrm{abc}$ & $-1.4 \mathrm{~d}$ & $29.6 \mathrm{abc}$ & $-0.3 \mathrm{a}$ & $165.3 \mathrm{a}$ \\
\hline & $40.9 \pm 1.6$ & $16.6 \pm 1.2$ & $19.5 \pm 1.4$ & $0.7 \pm 0.0$ & $217.5 \pm 2.2$ & $58.6 \pm 1.7$ & $-6.3 \pm 1.2$ & $34.6 \pm 2.0$ & $-0.8 \pm 0.1$ & $133.9 \pm 7.2$ \\
\hline
\end{tabular}

Means with the same letter are not different according to the Tukey's test at 0.05 level, $n=14$.

\begin{tabular}{lccc}
\hline B) L red & a red & b red & Hue red \\
\hline $32.1 \pm 1.2$ & $7.9 \pm 0.5$ & $8.8 \pm 1.2$ & $226.2 \pm 4.1$ \\
\hline
\end{tabular}

Means with the same letter are not different according to

the Tukey's test at 0.05 level, $n=6$.

to 31.6 (selection ' 10.02 ') dividing plant selections into four groups of significance. $\mathrm{L}^{*} \mathrm{a}^{*}$ and $\mathrm{b}^{*}$ values for green express colour background of the skin. According to $\mathrm{L}$ and $\mathrm{a}^{*}$ the plants were divided into four groups and the range was between 49.8 and 67.8 (selections '10.05' and '10.02') and -12.8 and 0.0 (selections '10.03' and '10.05') respectively. Regarding Hue green plant selections were grouped in three homogeneous categories with minimum values 101.7 (selection '10.12') and maximum 172.1 (selection '10.05').

In Table 4 plant selections average red parameters for skin colour of bletted fruits are also shown and they of course differed from those of ripe fruits but no differences were found among plant selections.

\subsection{Chemical analysis}

Data reported in this paragraph are means of two years records, for ripe fruits only.

\subsubsection{Titratable acid}

Regarding titratable acidity (TA) of ripe fruit pulp according to the Tuckey's test, the selections were divided into seven homogeneous groups (Table 5). The values ranged from 6.0 MAE (selection '10.16') and 44 MAE (selection ' 10.12 ') with a gap of $86.4 \%$ between the lowest and the highest value.

A significant reduction in TA of bletted fruits was found (average 5.9 MAE to 12.2 MAE as recorded for ripe fruits). The average loss of acidity throughout the bletting process was of $60.6 \%$.

\subsubsection{Soluble solids content}

For the total soluble solids content (Table 5) again the selections were divided into seven homogeneous groups, the values were ranging from 19.3 (selection ' 10.05 ') and $31.8^{\circ} \mathrm{Bx}$ (selection '10.06') with a gap of $65 \%$ between the lowest and the highest. In bletted fruits minimum and maximum TSS scored was 15.2 and $20.9^{\circ} \mathrm{Bx}$ (selection 
Table 5

Chemical characterization of service tree fruits before (A) and after bletting (B). TA $=$ Titratable acidity expressed as mEq malic acid per $100 \mathrm{~g}$ fresh weight of fruit. TSS $=$ Total soluble solids content expressed as ${ }^{\circ} \mathrm{Bx}$. Means with the same letter are not different according to the Tukey's test at 0.05 level. $n=14(\mathrm{~A}), n=11(\mathrm{~B})$

\begin{tabular}{lll}
\hline A) Plant Selection & TA meq & TSS ${ }^{\circ} \mathrm{Bx}$ \\
\hline 9.04 & $9.6 \mathrm{bcde}$ & $21.8 \mathrm{abcde}$ \\
9.05 & $8.5 \mathrm{abcd}$ & $28.0 \mathrm{cde}$ \\
10.01 & $8.5 \mathrm{abcd}$ & $19.7 \mathrm{ab}$ \\
10.02 & $9.0 \mathrm{bcd}$ & $24.9 \mathrm{ef}$ \\
10.03 & $14.2 \mathrm{f}$ & $27.2 \mathrm{f}$ \\
10.04 & $10.9 \mathrm{cde}$ & $22.2 \mathrm{bcde}$ \\
10.05 & $7.3 \mathrm{abc}$ & $19.3 \mathrm{ab}$ \\
10.06 & nd & $31.8 \mathrm{~g}$ \\
10.08 & $12.0 \mathrm{cdef}$ & $27.3 \mathrm{f}$ \\
10.11 & $8.0 \mathrm{ab}$ & $21.0 \mathrm{abc}$ \\
10.12 & $44.0 \mathrm{~g}$ & $24.5 \mathrm{def}$ \\
10.14 & $13.5 \mathrm{f}$ & $24.7 \mathrm{abcd}$ \\
10.15 & $7.4 \mathrm{abc}$ & $24.9 \mathrm{ef}$ \\
10.16 & $6.0 \mathrm{a}$ & $18.9 \mathrm{a}$ \\
mean & $12.2 \pm 2.6$ & $25.7 \pm 0.8$ \\
\hline
\end{tabular}

\begin{tabular}{lcc}
\hline B) Plant selection & TA meq & TSS $^{\circ} \mathrm{Bx}$ \\
\hline 9.05 & $5.8 \mathrm{~b}$ & $20.9 \mathrm{c}$ \\
10.01 & $\mathrm{nd}$ & $15.2 \mathrm{a}$ \\
10.04 & $4.5 \mathrm{ab}$ & $19.5 \mathrm{bc}$ \\
10.11 & $3.8 \mathrm{a}$ & $18.6 \mathrm{~b}$ \\
10.14 & $9.6 \mathrm{c}$ & $19.9 \mathrm{bc}$ \\
10.16 & $\mathrm{n} \mathrm{d}$ & $\mathrm{n} \mathrm{d}$ \\
Mean & $5.9 \pm 1.3$ & $16.0 \pm 2.9$ \\
\hline
\end{tabular}

'10.01' and '9.05' respectively). Also in this case a significant reduction in average TSS between the two ripening phases was found, giving the chance to suspect, together with the TA diminution, some fermentation phenomena.

\subsubsection{Estimation of phenolic content by the Folin-Ciocalteu test}

Extracts in $\mathrm{HCl}$ of ripe fruits (Table 6A) showed that in terms of phenolic content the plants were divided into 4 homogeneous groups and values varied from minimum 2094.6 CAE (selection '10.16') to maximum 5142.0 CAE (selection '10.14') for an increase of $145 \%$ compared to the plant showing the lowest value. Phenolic content in $\mathrm{EtOH}$ extracts divided plant selections into six homogeneous groups with values ranging between $391.1 \mathrm{CAE}$ and 1038.6 CAE with an increase of $165 \%$ : again selection ' 10.16 ' scored the minimum and selection ' 10.14 ' scored the maximum. Analyzing the total content of phenols obtained from the sum of the two extracts values ranged between 2485.7 CAE (selection '10.16') and 6180.6 CAE (selection '10.14') corresponding to an increase of 148\% in respect to selection ' 10.16 '. Regarding bletted fruits no statistically significant differences could be detected for phenolic content within plant selections but there was a significant fall of total phenols (averaging about 60 folds) content in bletted fruits for all analyzed plant selections (Table 6B).

\subsubsection{Flavonoids}

Flavonoids showed a lower variability within plant selections comparing with phenolic content (Table 6A). Values for $\mathrm{HCl}$ extracts ranged between $696.8 \mathrm{CE}$ and $3462.7 \mathrm{CE}$ while for $\mathrm{EtOH}$ extracts the range was relatively narrower: 
Table 6

Phenolic composition of ripe (A) and bletted (B) fruits. Units are chlorogenic acid equivalents (CAE/100 g fw) for the phenols amount, catechin equivalents (CE/100 g fw) for flavonoids, and gallic acid equivalents (GAE/100 g fw) for gallic acid, NH, non hydrolyzed samples, $\mathrm{H}$, hydrolyzed samples. C); composition of ripe fruits in terms of gallic acid and its derivative D) composition of bletted fruits in terms of gallic acid and its derivative. E) Variation in percentage of gallic acid and its derivative content in $(\mathrm{H})$ and $(\mathrm{NH})$-samples in the course of ripening. Values are the result of: [(gallic acid and its derivative content in bletted fruit)-(gallic acid and its derivative content in ripe fruit)] $* 100 /$ gallic acid and its derivative content in ripe fruit. Means with the same letter in each column are not different according to the Tukey's test at 0.05 level, $n=10$ (A) and $n=9(\mathrm{~B})$

\begin{tabular}{|c|c|c|c|c|c|c|c|}
\hline A) Plant selection & Phenols $\mathrm{HCl}$ & Phenols EtOH & Phenols total & Flavonoids $\mathrm{HCl}$ & Flavonoids EtOH & Flavonoids total & Flavonoids/phenols \\
\hline 9.04 & $2637.0 \mathrm{a}$ & $556.4 \mathrm{bc}$ & $3193.5 \mathrm{a}$ & $1171.6 \mathrm{ab}$ & $468.6 \mathrm{ab}$ & $1640.2 \mathrm{a}$ & $51.3 \mathrm{a}$ \\
\hline 9.05 & $4536.4 \mathrm{bcd}$ & $614.4 \mathrm{~cd}$ & $5150.9 b c$ & $1289.3 \mathrm{ab}$ & $515.7 \mathrm{ab}$ & $1805.0 \mathrm{ab}$ & $35.4 \mathrm{a}$ \\
\hline 10.01 & $3681.8 \mathrm{abc}$ & $546.8 \mathrm{bc}$ & 4228.6abc & $959.8 \mathrm{a}$ & $460.8 \mathrm{ab}$ & $1420.6 \mathrm{a}$ & $32.4 \mathrm{a}$ \\
\hline 10.02 & $3626.1 \mathrm{abc}$ & $505.8 \mathrm{abc}$ & 4131.9abc & $1088.7 \mathrm{ab}$ & $427.6 \mathrm{ab}$ & $1516.3 \mathrm{a}$ & $36.6 \mathrm{a}$ \\
\hline 10.03 & $4875.1 \mathrm{~cd}$ & $778.9 \mathrm{e}$ & $5654.0 \mathrm{c}$ & $1622.9 \mathrm{ab}$ & $649.2 b c$ & $2272.1 \mathrm{ab}$ & $40.1 \mathrm{a}$ \\
\hline 10.04 & $3015.0 \mathrm{ab}$ & $755.7 \mathrm{de}$ & $3770.7 \mathrm{ab}$ & $1576.4 \mathrm{ab}$ & $630.6 b c$ & $2207.0 \mathrm{ab}$ & $65.6 \mathrm{a}$ \\
\hline 10.11 & $2664.1 \mathrm{a}$ & $442.8 \mathrm{ab}$ & $3106.9 \mathrm{a}$ & 941.1a & $376.4 \mathrm{ab}$ & $1317.6 \mathrm{a}$ & $42.5 \mathrm{a}$ \\
\hline 10.14 & $5142.0 \mathrm{~d}$ & $1038.6 \mathrm{f}$ & $6180.6 \mathrm{~d}$ & $3462.7 b$ & $859.9 \mathrm{c}$ & $4322.6 b$ & $72.0 \mathrm{a}$ \\
\hline 10.15 & $3726.2 \mathrm{abcd}$ & 485.6abc & $4211.8 \mathrm{abc}$ & $1087.4 \mathrm{ab}$ & $411.2 \mathrm{ab}$ & $1498.5 \mathrm{a}$ & $35.5 \mathrm{a}$ \\
\hline 10.16 & $2094.6 a$ & $391.1 \mathrm{a}$ & $2485.7 \mathrm{a}$ & $696.8 \mathrm{a}$ & $334.5 \mathrm{a}$ & $1031.3 \mathrm{a}$ & $40.3 \mathrm{a}$ \\
\hline Mean & $3599.8 \pm 322$ & $611.6 \pm 62$ & $4211 \pm 369$ & $1167.9 \pm 247$ & $513.5 \pm 50.1$ & $1903.1 \pm 294.6$ & $45.2 \pm 4.3$ \\
\hline
\end{tabular}

\begin{tabular}{lccc}
\hline B) Plant selection & Phenols HCl & Phenols EtOH & phenols total \\
\hline 9.05 & $56.3 \mathrm{a}$ & $21.5 \mathrm{a}$ & $77.8 \mathrm{a}$ \\
10.01 & $79.7 \mathrm{a}$ & $15.8 \mathrm{a}$ & $95.5 \mathrm{a}$ \\
10.04 & $43.1 \mathrm{a}$ & $16.2 \mathrm{a}$ & $59.3 \mathrm{a}$ \\
10.11 & $58.0 \mathrm{a}$ & $13.4 \mathrm{a}$ & $71.4 \mathrm{a}$ \\
10.14 & $72.1 \mathrm{a}$ & $17.9 \mathrm{a}$ & $90.0 \mathrm{a}$ \\
10.16 & $57.5 \mathrm{a}$ & $16.0 \mathrm{a}$ & $73.5 \mathrm{a}$ \\
Mean & $61.1 \pm 5.3$ & $16.8 \pm 1.1$ & $77.9 \pm 5.4$ \\
\hline
\end{tabular}

\begin{tabular}{lcccccc}
\hline $\begin{array}{l}\text { C) Plant } \\
\text { selection }\end{array}$ & $\begin{array}{c}\text { Gallic acid } \\
(\mathrm{NH})\end{array}$ & $\begin{array}{c}\text { Gallic acid } \\
(\mathrm{H})\end{array}$ & $\begin{array}{c}\text { Gallic acid } \\
\text { derivative }(\mathrm{NH})\end{array}$ & $\begin{array}{c}\text { Gallic acid } \\
\text { derivative }(\mathrm{H})\end{array}$ & $\begin{array}{c}\text { Total gallic } \\
\text { acid + derivative }(\mathrm{NH})\end{array}$ & $\begin{array}{c}\text { Total gallic } \\
\text { acid }+ \text { derivative }(\mathrm{H})\end{array}$ \\
\hline 9.04 & $8.5 \mathrm{bc}$ & $12.2 \mathrm{bc}$ & $329.6 \mathrm{c}$ & $406.9 \mathrm{~cd}$ & $338.0 \mathrm{c}$ & $419.1 \mathrm{~cd}$ \\
9.05 & $8.6 \mathrm{bc}$ & $13.4 \mathrm{bc}$ & $310.1 \mathrm{c}$ & $417.6 \mathrm{~cd}$ & $318.7 \mathrm{c}$ & $431.0 \mathrm{~cd}$ \\
10.01 & $6.8 \mathrm{ab}$ & $10.6 \mathrm{abc}$ & $245.0 \mathrm{bc}$ & $380.3 \mathrm{bcd}$ & $251.8 \mathrm{bc}$ & $390.9 \mathrm{bcd}$ \\
10.02 & $6.2 \mathrm{ab}$ & $15.0 \mathrm{c}$ & $252.9 \mathrm{bc}$ & $483.9 \mathrm{~cd}$ & $259.1 \mathrm{bc}$ & $498.9 \mathrm{~d}$ \\
10.03 & $6.8 \mathrm{ab}$ & $9.1 \mathrm{abc}$ & $264.8 \mathrm{bc}$ & $303.5 \mathrm{abc}$ & $271.6 \mathrm{bc}$ & $312.6 \mathrm{abc}$ \\
10.04 & $4.1 \mathrm{ab}$ & $6.2 \mathrm{ab}$ & $154.4 \mathrm{ab}$ & $216.0 \mathrm{ab}$ & $158.5 \mathrm{ab}$ & $22.2 \mathrm{ab}$ \\
10.11 & $2.2 \mathrm{a}$ & $3.8 \mathrm{a}$ & $74.2 \mathrm{a}$ & $135.9 \mathrm{a}$ & $76.6 \mathrm{a}$ & $488.9 \mathrm{~d}$ \\
10.14 & $13.7 \mathrm{c}$ & $27.8 \mathrm{~d}$ & $475.2 \mathrm{~d}$ & $1043.2 \mathrm{e}$ & $345.5 \mathrm{c}$ & $139.7 \mathrm{a}$ \\
10.15 & $9.3 \mathrm{bc}$ & $13.4 \mathrm{bc}$ & $336.2 \mathrm{~cd}$ & $523.5 \mathrm{~d}$ & $274.3 \mathrm{bc}$ & $536.9 \mathrm{~d}$ \\
10.16 & $6.6 \mathrm{ab}$ & $8.9 \mathrm{abc}$ & $267.7 \mathrm{bc}$ & $363.7 \mathrm{bcd}$ & $278.3 \pm 10.5$ & $372.6 \mathrm{bcd}$ \\
Mean & $7.1 \pm 1.6$ & $11.5 \pm 3.5$ & $262.0 \pm 57.1$ & $431 \pm 133.8$ & & $439.49 \pm 15.9$ \\
\hline
\end{tabular}


Table 6

(Continued)

\begin{tabular}{lcccccc}
\hline $\begin{array}{l}\text { D) plant } \\
\text { selection }\end{array}$ & $\begin{array}{c}\text { Gallic acid } \\
(\mathrm{NH})\end{array}$ & $\begin{array}{c}\text { Gallic acid } \\
(\mathrm{H})\end{array}$ & $\begin{array}{c}\text { Gallic acid } \\
\text { derivative }(\mathrm{NH})\end{array}$ & $\begin{array}{c}\text { Gallic acid } \\
\text { derivative }(\mathrm{H})\end{array}$ & $\begin{array}{c}\text { Total gallic } \\
\text { acid+derivative }(\mathrm{NH})\end{array}$ & $\begin{array}{c}\text { Total gallic } \\
\text { acid }+ \text { derivative }(\mathrm{H})\end{array}$ \\
\hline 9.05 & $6.5 \mathrm{a}$ & $31.1 \mathrm{bc}$ & $120.2 \mathrm{a}$ & $505.5 \mathrm{a}$ & $120.2 \mathrm{a}$ & $456.3 \mathrm{a}$ \\
10.01 & $3.5 \mathrm{a}$ & $13.9 \mathrm{a}$ & $124.7 \mathrm{a}$ & $500.9 \mathrm{a}$ & $126.7 \mathrm{a}$ & $498.8 \mathrm{a}$ \\
10.04 & $5.8 \mathrm{a}$ & $16.0 \mathrm{a}$ & $147.1 \mathrm{a}$ & $440.3 \mathrm{a}$ & $127.3 \mathrm{a}$ & $514.8 \mathrm{a}$ \\
10.11 & $5.4 \mathrm{a}$ & $22.0 \mathrm{ab}$ & $122.0 \mathrm{a}$ & $476.9 \mathrm{a}$ & $128.2 \mathrm{a}$ & $515.7 \mathrm{a}$ \\
10.14 & $8.4 \mathrm{a}$ & $15.0 \mathrm{a}$ & $116.8 \mathrm{a}$ & $500.7 \mathrm{a}$ & $152.9 \mathrm{a}$ & $536.6 \mathrm{a}$ \\
10.16 & $3.1 \mathrm{a}$ & $36.4 \mathrm{c}$ & $221.9 \mathrm{a}$ & $920.8 \mathrm{~b}$ & $229.9 \mathrm{a}$ & $957.2 \mathrm{~b}$ \\
Mean & $5.4 \pm 0.8$ & $22.4 \pm 3.8$ & $142.1 \pm 16.5$ & $557.5 \pm 73.3$ & $147.5 \pm 6.5$ & $579.9 \pm 13.7$ \\
\hline
\end{tabular}

\begin{tabular}{lrr}
\hline E) Plant selection & $(\mathrm{H}) \%$ & $(\mathrm{NH}) \%$ \\
\hline 9.05 & 24.5 & -60.2 \\
10.01 & 31.7 & -49.1 \\
10.04 & 105.4 & -3.5 \\
10.11 & 257.1 & 66.6 \\
10.14 & -51.8 & -75.4 \\
10.16 & 156.9 & -16.2 \\
mean & 87.3 & -23.0 \\
\hline
\end{tabular}

334.5 CE over 859.9 CE. Regarding total flavonoids plant selections that showed the lowest and the highest levels, as well as for $\mathrm{HCl}$ and $\mathrm{EtOH}$ extracts, were the same selections that showed the lowest and the highest phenolic content i.e. selections ' 10.16 ' and ' 10.14 ' respectively.

\subsubsection{Single phenols}

Our qualitative data (not shown) highlighted that widely dominant phenolic compounds were characterized by a spectrum with maximum absorption at $280 \mathrm{~nm}$ that was identified as gallic acid, in addition a derivative of gallic acid, likely an ester of gallic acid (Atoui et al. [1]) and finally a band corresponding to polymerized tannins. Hydroxycinnamic acids and flavonols were present in much lower quantities this indicating that the main phenolic compounds nature of our service fruit selections were hydrolysable tannins: so from a quantitative point of view we focused on gallic acid content and on its derivative compound (Table 6C). The most relevant compound was related to the gallic acid derivative, with a content of about 35 times higher than gallic acid in all samples. Plant selection ' 10.14' showed the highest content of both gallic acid and its derivative independently on the sample ( $\mathrm{H}$ and $\mathrm{NH})$. Bletted fruit (NH)- samples did not show significant differences among plant selections in terms of gallic acid and its derivative (Table 6D); regarding bletted fruit plant selection '10.16' $(\mathrm{H})$ - samples scored the maximum content both for gallic acid, its derivative and the sum of the two.

In the course of ripening $(\mathrm{H})$-samples differed from $(\mathrm{NH})$-samples in terms of percentage increase of gallic acid: a part for selection ' 10.14 ' bletted fruit of (H)-samples showed an increase in acid gallic content while (NH)-samples, a part for selection ' 10.11 ', showed a decrease (Table $6 \mathrm{E}$ ).

\subsection{Functional characterization}

The $(\mathrm{H})$-samples were not assayed by the DPPH test due to the acidity of the matrix interfering with the EPR lecture of the radical. Comparisons between $(\mathrm{H})$ and $(\mathrm{NH})$ extracts was only made by CBA method.

\subsubsection{DPPH-EPR scavenging method}

In Table 7, showing the results obtained from the DPPH-EPR assay on $\mathrm{HCl}$ extracts of ripe fruits, values ranged from 64.2 TE (selection '10.01') and 222.1 TE (selection '10.14') for a difference of $246 \%$ in respect to plant selection 
Table 7

Antioxidant assays on ripe (A) and bletted (B) fruits. Units are Trolox equivalents (TE/100 g fw). NH, non hydrolyzed sample; H, hydrolyzed samples. Means with the same letter in each column are not different according to the Tukey's test at 0.05 level. $n=10$ (A) and $n=9$ (B)

\begin{tabular}{|c|c|c|c|c|c|c|c|c|c|}
\hline $\begin{array}{l}\text { A) Plant } \\
\text { selection }\end{array}$ & $\begin{array}{l}\mathrm{EPR} \\
\mathrm{HCl}\end{array}$ & $\begin{array}{c}\text { EPR } \\
\text { EtOH }\end{array}$ & $\begin{array}{l}\text { EPR } \\
\text { total }\end{array}$ & $\begin{array}{c}\mathrm{CBA} \\
\mathrm{HCl}(\mathrm{NH})\end{array}$ & $\begin{array}{c}\text { CBA } \\
\text { EtOH }(\mathrm{NH})\end{array}$ & $\begin{array}{c}\mathrm{CBA} \\
\text { total }(\mathrm{NH})\end{array}$ & $\begin{array}{c}\mathrm{CBA} \\
\mathrm{HCl}(\mathrm{H})\end{array}$ & $\begin{array}{c}\text { CBA } \\
\text { EtOH }(\mathrm{H})\end{array}$ & $\begin{array}{c}\text { CBA } \\
\text { Total }(\mathrm{H})\end{array}$ \\
\hline 9.04 & $71.6 \mathrm{a}$ & $72.0 \mathrm{e}$ & $143.7 \mathrm{abc}$ & $137.2 \mathrm{ab}$ & $80.7 \mathrm{a}$ & $217.9 \mathrm{ab}$ & $10.1 \mathrm{a}$ & $4.9 \mathrm{a}$ & $15.1 \mathrm{a}$ \\
\hline 9.05 & $99.7 \mathrm{ab}$ & $25.2 \mathrm{abc}$ & $124.9 \mathrm{abc}$ & $499.7 \mathrm{~cd}$ & $79.3 \mathrm{a}$ & $579.0 \mathrm{c}$ & $109.7 \mathrm{~d}$ & $37.9 \mathrm{~cd}$ & $147.6 \mathrm{~d}$ \\
\hline 10.01 & $71.0 \mathrm{a}$ & $14.8 \mathrm{a}$ & 85.8ab & $63.5 \mathrm{a}$ & $107.0 \mathrm{a}$ & $170.5 \mathrm{a}$ & $97.9 \mathrm{~cd}$ & $23.1 \mathrm{bc}$ & $121.1 \mathrm{~cd}$ \\
\hline 10.02 & $114.4 \mathrm{ab}$ & $41.5 \mathrm{~cd}$ & $156.0 \mathrm{bc}$ & $135.3 \mathrm{ab}$ & $65.3 \mathrm{a}$ & $200.7 \mathrm{ab}$ & $23.6 \mathrm{ab}$ & $7.0 \mathrm{a}$ & $30.6 \mathrm{ab}$ \\
\hline 10.03 & $126.2 \mathrm{ab}$ & $32.0 \mathrm{abc}$ & $158.2 \mathrm{bc}$ & $671.0 \mathrm{~d}$ & $256.1 \mathrm{c}$ & $927.1 d$ & $73.8 \mathrm{bcd}$ & $48.2 \mathrm{~d}$ & $122.0 \mathrm{~cd}$ \\
\hline 10.04 & $144.2 \mathrm{~b}$ & $32.5 \mathrm{abc}$ & $176.7 \mathrm{c}$ & $349.6 b c$ & $127.4 \mathrm{ab}$ & $477.0 \mathrm{bc}$ & $41.1 \mathrm{abc}$ & $26.0 \mathrm{bc}$ & 67.0abc \\
\hline 10.11 & $64.2 \mathrm{a}$ & $18.8 \mathrm{ab}$ & $83.0 \mathrm{a}$ & $148.6 \mathrm{ab}$ & $52.3 \mathrm{a}$ & $200.8 \mathrm{ab}$ & $31.9 \mathrm{ab}$ & $12.4 \mathrm{ab}$ & $44.3 \mathrm{ab}$ \\
\hline 10.14 & $222.1 \mathrm{c}$ & $52.9 \mathrm{~d}$ & $275.0 \mathrm{~d}$ & $479.7 \mathrm{~cd}$ & $223.5 b c$ & $703.2 \mathrm{~cd}$ & $67.8 \mathrm{bcd}$ & $20.4 b$ & $88.2 \mathrm{bcd}$ \\
\hline 10.15 & $102.6 \mathrm{ab}$ & $34.0 \mathrm{abc}$ & $136.5 \mathrm{abc}$ & $125.1 \mathrm{ab}$ & $71.9 \mathrm{a}$ & $197.0 \mathrm{ab}$ & $25.0 \mathrm{ab}$ & $6.8 \mathrm{a}$ & $31.8 \mathrm{ab}$ \\
\hline 10.16 & $71.3 \mathrm{a}$ & $39.4 \mathrm{bc}$ & $110.7 \mathrm{abc}$ & $79.42 \mathrm{a}$ & $57.4 \mathrm{a}$ & $136.8 \mathrm{a}$ & $40.1 \mathrm{abc}$ & $1.5 \mathrm{a}$ & $41.7 \mathrm{ab}$ \\
\hline mean & $108.7 \pm 15.2$ & $36.3 \pm 5.3$ & $145.0 \pm 17.4$ & $268.9 \pm 67.8$ & $112.1 \pm 22.6$ & $381.0 \pm 86.9$ & $52.1 \pm 10.6$ & $18.8 \pm 4.8$ & $70.9 \pm 14.6$ \\
\hline B) Plant & EPR & EPR & EPR & CBA & CBA & $\mathrm{CBA}$ & $\mathrm{CBA}$ & $\mathrm{CBA}$ & CBA \\
\hline selection & $\mathrm{HCl}$ & $\mathrm{EtOH}$ & total & $\mathrm{HCl}(\mathrm{NH})$ & EtOH $(\mathrm{NH})$ & Total $(\mathrm{NH})$ & $\mathrm{HCl}(\mathrm{H})$ & $\mathrm{EtOH}(\mathrm{H})$ & Total $(\mathrm{H})$ \\
\hline 9.05 & $3.2 \mathrm{a}$ & $1.2 \mathrm{a}$ & $4.4 \mathrm{a}$ & $21.6 \mathrm{a}$ & $5.2 \mathrm{a}$ & $26.8 \mathrm{a}$ & $1.1 \mathrm{a}$ & $0.8 \mathrm{a}$ & $1.9 \mathrm{a}$ \\
\hline 10.01 & $2.1 \mathrm{a}$ & $1.4 \mathrm{a}$ & $3.5 \mathrm{a}$ & $7.6 \mathrm{a}$ & $2.6 \mathrm{a}$ & $10.3 \mathrm{a}$ & $1.2 \mathrm{a}$ & $0.5 \mathrm{a}$ & $1.8 \mathrm{a}$ \\
\hline 10.04 & $3.3 \mathrm{a}$ & $1.8 \mathrm{a}$ & $5.1 \mathrm{a}$ & $11.0 \mathrm{a}$ & $3.3 \mathrm{a}$ & $14.3 \mathrm{a}$ & $1.3 \mathrm{a}$ & $0.5 \mathrm{a}$ & $1.8 \mathrm{a}$ \\
\hline 10.11 & $2.3 \mathrm{a}$ & $0.9 \mathrm{a}$ & $3.3 \mathrm{a}$ & $5.7 \mathrm{a}$ & $23.9 \mathrm{a}$ & $29.6 \mathrm{a}$ & $1.5 \mathrm{a}$ & $0.7 \mathrm{a}$ & $2.2 \mathrm{a}$ \\
\hline 10.14 & $4.8 \mathrm{a}$ & $1.4 \mathrm{a}$ & $6.2 \mathrm{a}$ & $4.4 \mathrm{a}$ & $4.9 \mathrm{a}$ & $9.4 \mathrm{a}$ & $1.3 \mathrm{a}$ & $1.0 \mathrm{a}$ & $2.3 \mathrm{a}$ \\
\hline 10.16 & $5.4 \mathrm{a}$ & $1.0 \mathrm{a}$ & $6.4 \mathrm{a}$ & $16.4 \mathrm{a}$ & $6.5 \mathrm{a}$ & $22.9 \mathrm{a}$ & $0.6 \mathrm{a}$ & $0.2 \mathrm{a}$ & $0.9 \mathrm{a}$ \\
\hline mean & $3.5 \pm 0.5$ & $1.3 \pm 0.1$ & $4.5 \pm 0.6$ & $11.1 \pm 2.7$ & $7.7 \pm 3.2$ & $18.9 \pm 3.5$ & $1.2 \pm 0.1$ & $0.6 \pm 0.1$ & $1.8 \pm 0.2$ \\
\hline
\end{tabular}

with the lowest activity. Considering this parameter, plants were divided into three groups, compared with five groups obtained from the EtOH extracts and four groups obtained from the sum of the values of the two extracts. EtOH extracts showed a general lower activity than $\mathrm{HCl}$ extracts, the minimum value was $14.8 \mathrm{TE}$ (selection '10.01') while the highest was $72.0 \mathrm{TE}$ (selection '9.04') with a difference of 385\%. Antioxidant activity from the sum of the two extracts (total) ranged between $83 \mathrm{TE}$ and $275.0 \mathrm{TE}$ with an increase of $231 \%$, confirming that plant selection ' 10.14 ' had the highest antioxidant activity while the lowest was attributed to selection ' 10.11 '. As indicated in Table 7 a dramatic drop in antioxidant activity for any kind of extract was recorded in bletted fruits and such a reduction cancelled differences among plant selections.

\subsubsection{CBA scavenging method}

Also with CBA method plant selections were divided into three, five and four homogeneous groups according to antioxidant activity as recorded for $\mathrm{HCl}, \mathrm{EtOH}$ and the sum of the two extracts, respectively (Table 7). For (NH)- $\mathrm{HCl}$ extracts the value ranged between 63.5 TE (selection '10.01') and 671.0 TE (selection '10.03') with 956\% increase, while for (NH)-EtOH extracts the range was narrower: 52.3 TE (selection '10.02') and 256.1 (selection '10.03') with $389 \%$ increase. Finally for the sum of the two, limit values detected for (NH)-total, were $136.8 \mathrm{TE}$ (selection ' 10.16 ') and 927.1 TE (selection ' 10.03 '). This assay, which differs from the previous one for greater biological relevance, confirms that plant selection ' 10.14 ' and '10.16' are respectively in the highest and lowest antioxidant activity class.

Regarding $(\mathrm{H})$-samples plant selections are divided for each kind of extract in four homogeneous groups. $\mathrm{HCl}$ extracts were ranging from 10.1 TE (selection '9.04') to 109.7 TE (selection '9.05'), EtOH extracts from $1.5 \mathrm{TE}$ (selection ' 10.16 ') to $48.2 \mathrm{TE}$ (selection ' 10.03 ') and finally for total antioxidant activity the range was between 15.1 TE (selection '9.04') and 147.6 TE (selection '9.05'). Extract hydrolysis led to a significant reduction in particular for both $\mathrm{HCl}$ extract and total antioxidant activity. 
Table 8

Correlation between (A) fruit morphological and chemical parameters and (B) fruit chemical and functional parameters. Two-tailed Pearson's ' $r$ ' are shown. ' $r$ ' varies from -1 to +1 . with 0 indicating no relationship and 1 indicating perfect relationship. $L I=L L * L W * l e a f l e t ~ n u m b e r$. In bolt bletted fruits values

\begin{tabular}{lcccccccc}
\hline A) & Weight & Equatorial $\emptyset$ & Polar/equatorial $\emptyset$ & HUE green & TSS & T A & TSS/ TA & Seed $(n)$ \\
\hline Weight & & 0.9 & -0.4 & -0.3 & 0.4 & & -0.2 & \\
Seed $(n)$ & $0.2^{* *}$ & & -0.5 & & & & & \\
LI & 0.4 & & & $-0.5^{* *}$ & -0.4 & & 0.3 \\
\hline
\end{tabular}

\begin{tabular}{|c|c|c|c|c|c|c|c|c|c|c|c|c|}
\hline B) & $\begin{array}{l}\text { CBA } \\
(\mathrm{NH})\end{array}$ & $\begin{array}{c}\text { CBA } \\
(\mathrm{H})\end{array}$ & $\begin{array}{c}\text { EPR } \\
(\mathrm{EtOH})\end{array}$ & $\begin{array}{l}\text { Flavon } \\
\text { EtOH }\end{array}$ & $\begin{array}{c}\text { Flavon } \\
\mathrm{HCl}\end{array}$ & $\begin{array}{c}\text { Flavon } \\
\text { total }\end{array}$ & $\begin{array}{c}\text { Phenols } \\
\mathrm{HCl}\end{array}$ & $\begin{array}{c}\text { Phenols } \\
\text { EtOH }\end{array}$ & $\begin{array}{c}\text { Phenols } \\
\text { total }\end{array}$ & $\begin{array}{c}\text { Gallic } \\
\text { acid }(\mathrm{NH})\end{array}$ & $\begin{array}{c}\text { Gallic } \\
\text { acid }(\mathrm{NH})\end{array}$ & $\begin{array}{l}\text { Gallic acid } \\
\text { deriv }(\mathrm{NH})\end{array}$ \\
\hline LI & & $-0.5^{*}$ & & & & & & & & & & \\
\hline Gallic acid $(\mathrm{H})$ & & & & & & & & & $0.6^{* *}$ & & & \\
\hline Gallic acid (NH) & & & & & & & & & $0.6^{* *}$ & & & \\
\hline Gallic acid (NH) & $0.4 * *$ & & $0.6 * *$ & & & $0.7 * *$ & & & $0.5^{* *}$ & & & \\
\hline Gallic acid deriv (NH) & $0.6 * *$ & & $0.8 * *$ & & & $0.7 * *$ & & & $0.7 * *$ & & & \\
\hline EPR tot & $0.8 * *$ & $0.7 * *$ & & $0.8 * *$ & $0.6 * *$ & $0.7 * *$ & $0.6^{* *}$ & $0.8 * *$ & $0.7 * *$ & $0.7 * *$ & $0.6^{* *}$ & $0.8 * * \mathbf{0 . 5} *$ \\
\hline $\mathrm{CBA}(\mathrm{NH})$ & & & $0.8 * *$ & $0.7 * *$ & $0.7 * *$ & $0.7 * *$ & $0.7 * *$ & $0.7 * *$ & $0.7 * *$ & $0.5^{* *}$ & & \\
\hline $\mathrm{CBA}(\mathrm{H})$ & & & & $0.4 * * 0.4 * *$ & $0.6 * *$ & $0.6 * * 0.4 * *$ & $0.6 * *$ & $0.4 * \mathbf{0 . 4} * *$ & $0.6^{* *}$ & & & \\
\hline Flavon tot & & & & & & & & & $1.0 * *$ & & & \\
\hline EPR & & & & & & & & & & & & \\
\hline$(\mathrm{HCl})$ & & & & $0.8 * *$ & $0.7 * *$ & $0.7 * *$ & $0.7 * *$ & $0.8 * *$ & $0.7 * *$ & & & $0.5^{*}$ \\
\hline
\end{tabular}

$* P=0.05 ; * * P=0.01$.

Data statistical analysis of bletted fruits, did not found significant differences among the considered plant selections (Table 7).

According to both total $(\mathrm{NH})$ and $(\mathrm{H})$ a significant interaction was found between plant selection $\times$ ripening stage. The highest antioxidant activity was in general recorded for ripe fruits except for plant selection '10.16' (total-H) and '10.01' and '10.16' (total-NH) whose antioxidant activity did not change significantly between ripe and bletted fruits.

\subsection{Correlations}

Leaf index was either negatively correlated with TSS, TA, CBA $(\mathrm{H})$ and positively correlated with fruit weight and seed number (Table 8A). Fruit weight was positively correlated with equatorial diameter, TSS and a slight (Pearson's coefficient $=0.2)$ but highly significant correlation $(P=0.01)$ with seed number and negatively correlated with the ratio between the two diameters, HUE green and TSS/TA (Table 8A).

Significant correlations between functional parameters were also found (Table 8B). Obviously enough the highest correlations were recorded for total phenols, flavonoids and antioxidant activity as determined by the two tests. Only for $\mathrm{NH}$ samples a positive correlation between both gallic acid and its derivative and the two scavenging tests was found and, in general, the gallic acid derivative showed a higher degree of correlation than gallic acid. For bletted fruits such correlations dropped but nevertheless for the acid gallic derivative a significant correlation with total EPR and EPR-HCl was found. Regarding the two tests used to determine fruit antioxidant capacity they were linked by a high relationship, scoring Pearson's coefficient 0.7 and 0.8 for $(\mathrm{H})$ and $(\mathrm{NH})$ samples respectively.

\subsection{Discriminant analysis}

Discriminant analysis (DA) was performed on ten plants (Table 1) and only on ripe fruits, to check the validity of fruit morphologic, chemical and functional parameters for classifying plant selections. 16 variables passed the tolerance test (Table 9C). First nine canonical discriminant functions were used in the analysis, explaining $100 \%$ 
Table 9

Discriminant analysis report: A- Eigen values. Total variance and percentage cumulative variance. B- Significance test (Wilks' Lambda) for the two first linear functions. Pooled within groups correlations between discriminating variables and the first two standardized canonical discriminant functions. *largest absolute correlation between each variable and any discriminant function. C- probabilities (\%) of group membership appartenance

\begin{tabular}{lcccc}
\hline A) & \multicolumn{4}{c}{ Eigen values } \\
\hline Function & Eigen value & \% of variance & Cumulative \% & Canonical correlation \\
1 & $686.932 \mathrm{a}$ & 85.6 & 85.6 & 0.999 \\
2 & $50.266 \mathrm{a}$ & 6.3 & 91.8 & 0.999 \\
B) & \multicolumn{2}{c}{ Wilks' Lambda } \\
Test of functions & Wilks' Lambda & Chi-square & $\mathrm{df}$ & Sig. \\
1 Through 9 & 0.000 & 355.513 & 153 & 0.000 \\
2 Through 9 & 0.000 & 254.241 & 128 & 0.000 \\
\hline
\end{tabular}

a. First 9 canonical discriminant functions were used in the analysis.

\begin{tabular}{lrc}
\hline B) Structure matrix & & Function \\
\hline & 1 & \multicolumn{1}{c}{2} \\
TA & $0.301^{*}$ & 0.096 \\
a red & -0.049 & $-0.366^{*}$ \\
Polar $\varnothing$ & 0.005 & 0.041 \\
Polar/equatorial & 0.038 & 0.023 \\
L green & -0.054 & -0.075 \\
L red & 0.009 & 0.285 \\
b red & 0.029 & 0.308 \\
Seed number & -0.039 & -0.010 \\
HUE red & -0.003 & -0.057 \\
b green & 0.001 & 0.011 \\
CBA (H) & 0.088 & 0.060 \\
equatorial $\emptyset$ & -0.020 & 0.030 \\
T.S.S & 0.030 & 0.014 \\
Weight & -0.019 & 0.036 \\
a green & -0.054 & -0.148 \\
HUE green & 0.061 & 0.166 \\
\hline
\end{tabular}

\begin{tabular}{lrrrrrrrrrrrr}
\hline C) Plant selection & \multicolumn{10}{c}{ Group membership (\%) } \\
\hline & 904 & 905 & 1001 & 1002 & 1003 & 1004 & 1011 & 1014 & 1015 & 1016 & total \\
904 & 100.0 & 0.0 & 0.0 & 0.0 & 0.0 & 0.0 & 0.0 & 0.0 & 0.0 & 0.0 & 100.0 \\
905 & 0.0 & 100.0 & 0.0 & 0.0 & 0.0 & 0.0 & 0.0 & 0.0 & 0.0 & 0.0 & 100.0 \\
1001 & 0.0 & 0.0 & 100.0 & 0.0 & 0.0 & 0.0 & 0.0 & 0.0 & 0.0 & 0.0 & 100.0 \\
1002 & 0.0 & 0.0 & 0.0 & 100.0 & 0.0 & 0.0 & 0.0 & 0.0 & 0.0 & 0.0 & 100.0 \\
1003 & 0.0 & 0.0 & 0.0 & 0.0 & 100.0 & 0.0 & 0.0 & 0.0 & 0.0 & 0.0 & 100.0 \\
1004 & 0.0 & 0.0 & 0.0 & 0.0 & 0.0 & 100.0 & 0.0 & 0.0 & 0.0 & 0.0 & 100.0 \\
1011 & 0.0 & 0.0 & 0.0 & 0.0 & 0.0 & 0.0 & 100.0 & 0.0 & 0.0 & 0.0 & 100.0 \\
1014 & 0.0 & 0.0 & 0.0 & 0.0 & 0.0 & 0.0 & 0.0 & 100.0 & 0.0 & 0.0 & 100.0 \\
1015 & 0.0 & 0.0 & 0.0 & 0.0 & 0.0 & 0.0 & 0.0 & 0.0 & 100.0 & 0.0 & 100.0 \\
1016 & 0.0 & 0.0 & 0.0 & 0.0 & 0.0 & 0.0 & 0.0 & 0.0 & 0.0 & 100.0 & 100.0 \\
\hline
\end{tabular}




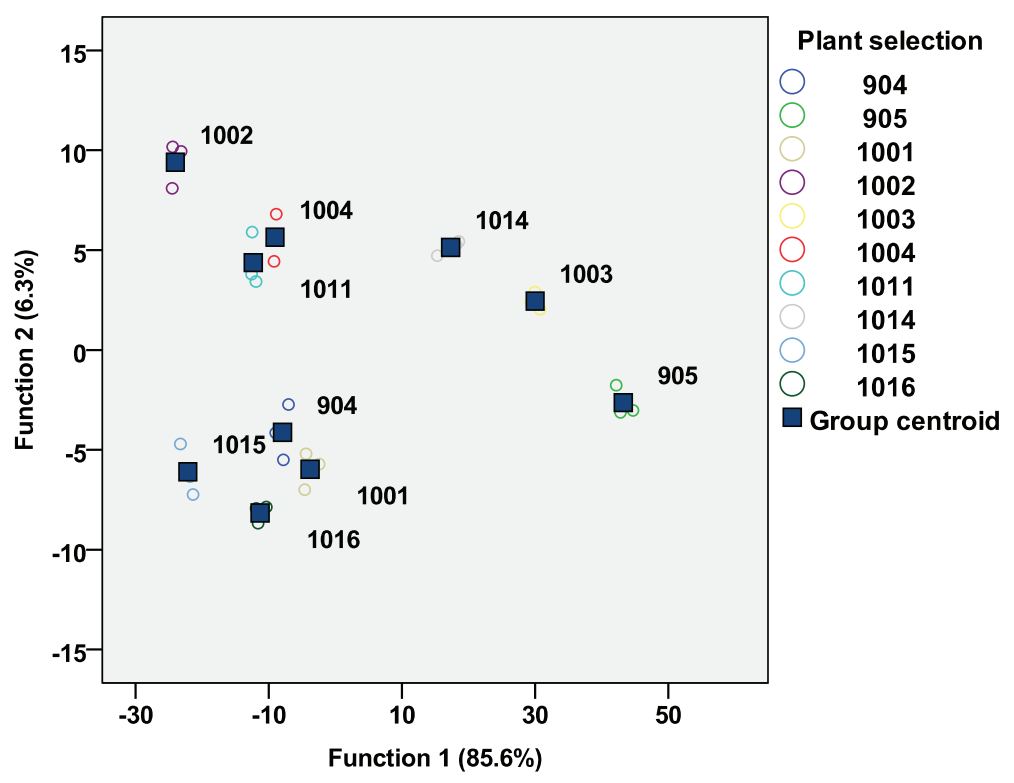

Fig. 1. Discriminant canonical function. Scatter plot of canonical scores for the first two canonical functions resulting from the discriminant analysis of ripe fruit morphological. chemical and functional parameters. The first two canonical functions effectively discriminate the 10 plant selections.

of the total variance, in particular function 1 and function 2 explained 91.8\% of total variance (Table 9A). Almost all morphological variables passed the tolerance test; regarding chemical parameters phenols component were not admitted while for functional properties related parameters only CBA total for $(\mathrm{H})$-samples was admitted for DA. The first discriminant function was positively correlated with titratable acidity (TA) the second function was negatively correlated with $\mathrm{a}^{*}$ red. According to this in fig. 1 are plotted plant selections each as a case in itself (Table 9C).

\section{Discussion}

In a larger project focused on fast growing S. domestica plants for timber production some selections were evaluated also for fruit characteristics and functional properties. Most marketed plants are commercially propagated by seed. Only a few plants are vegetatively (grafting) propagated and Italian nurseries are still selling service trees roughly distinguished on the basis of fruit shape (maliform-pyriform) this ignoring any other relevant characteristic of the tree/fruit [4].

As regard ripe fruits our plant selections showed variability for all scored parameters. The greatest part of plants showed apple-shaped fruits the remaining were pear-shaped.

A link between fertility and fruit characteristics is not surprising. For apple tree, that belongs to the same Family (Rosaceae) which genus Sorbus belongs to, after fertilization, seeds start producing hormones necessary for fruit development consequently the higher the seed count the better the final fruit set [7]. Fruit morphometric and quality parameters such as fruit length-to-width ratio, calcium content, firmness and acidity, are associated to seed number [9]. We found that seed number was correlated to fruit shape and weight. Morphological and chemical differences among plant selections were found particularly for titratable acidity, in fact, plant selection with the highest acidity showed values seven times higher than that with the lowest level; bletting contributed to mitigate such differences. Total phenols index is a chemical parameter quite important for varietal characterization. Phenolic substances content in fruit is strongly influenced by many factors outside the plant, such as climate and growing conditions. Plants considered in this research were grown under the same environmental conditions and the same cultural techniques and the analysis of phenols highlights genetic differences among such trees. Flavonoids content of bletted fruits 
could not be detected by the method of analysis used in this work, in fact, the absorbance level was not significantly different from background noise, consequently flavonoids has to be considered at a not detectable level.

Chromatograms obtained by reversed-phase HPLC analysis indicated that the phenolic compounds present in the matrix may be assimilated to three main classes of compounds: gallic acid, its derivative and polymeric tannins (detected at $280 \mathrm{~nm}$ ). In this research and in partial agreement with what was previously highlighted by Termentzi et al. $[12,14]$ we have ascertained the crucial role of gallic acid and its derivative in bletting process of service fruits. Changes in gallic acid amount and its derivative during bletting have to be considered as an indicator of post-harvest evolution of service fruit: a relatively limited loss of these compounds, as compared to loss in phenols, was observed in (NH)- samples of bletted fruits and in one case there was even an increase. In (H)-samples, contrariwise, there was a general increase. However, the phenolic content in Sorbus fruits was highly remarkable, with an average of 4211 total CAE, very high if compared to an apple (about 70-200 mg/100 g fw) [15].

Regarding the two tests used to evaluate antioxidant capacity, the first one, DPPH-EPR assay is considered of minor biological relevance because it involves a stabilized free radical by synthetic origin (1,1-diphenyl-2-picryl-hydrazyl) and it runs in a alien solvent (methanol) to plant and animal physiology. On the other hand it offers some advantages: easy to manage, very reproducible and it is often related to the presence of molecules with antioxidant activity.

The second one, CBA assay, is considered of high biological relevance because it simulates a more physiological situation: an oxidative stress which is involved in the oxidative degradation of biological membranes with the production of peroxyl radicals and a pigment of natural origin.

A linear and positive correlation was found between the two assays this indicating that easy to manage DPPH-EPR assay may be used for substrates at high phenol concentrations as the case of service fruits [10, 11].

Comparison between $(\mathrm{NH})$ and $(\mathrm{H})$ extracts shows that the latter expresses a lower antioxidant capacity this depending on the fact that plant antioxidants are mainly found in conjugated form (ie linked to sugars or organic acids), because in the wild-type form they are chemically unstable.

The high correlations found between total polyphenol content and antioxidant activity, demonstrates the relevant role of phenolic compounds in determining this activity. The low correlation between gallic acid content and at least one of the two test used to determine antioxidant capacity shows, however, that antioxidant capacity is not entirely explained by the presence of gallic acid and its derivatives, but also by other unidentified substances, included in the polyphenols index.

In the course of ripening $(\mathrm{H})$-samples differed from $(\mathrm{NH})$-samples in terms of percentage increase of gallic acid: this is explainable by the fact that ripe fruits contain a higher amount of tannins that are more stable to hydrolysis in respect to bletted fruits which contain a higher amount of soluble phenols.

In agreement with Termentzi et al. [14] we found that bletted fruits retain the lowest antioxidant power and according to this extraction from ripe fruits (veraison stage) ensures maximum yield.

Consumers prefer antioxidants of natural origin in food and medical products [10]; data from this research indicate that Sorbus domestica is a relevant source of natural antioxidants. Discriminant analysis confirmed our original hypothesis that plant selections are each as a case in itself and that fruit shape is not the only parameter which has to be used to classify a cultivar for fruit use. In this case titratable acidity and red colour of the skin had a relevant role in discriminating among plant selections. Plant selection '10.14', '10.03' and '9.05'combine high antioxidant activity with good morphological and chemical fruit characteristics and, accordingly with their timber value (wood technological performance will also be taken into account), they are going to be candidates for double aptitude plants. Finally, selection ' 10.03 ' is a candidate for triple aptitude plant in fact its erect and its majestic bearing, make it suitable also to urban decor (parks and gardens).

\section{Acknowledgments}

This research was partially funded by Lombardy Region (Project MOPROLEGNO).

\section{References}

[1] A.K. Atoui, A. Mansouri, G. Boskou and P. Kefalas, Tea and herbal infusions: Their antioxidant activity and phenolic profile, Food Chem 89 (2005), 27-36. 
[2] E. Bellini, E. Giordani, G. Giannelli and E. Picardi, Sorbo domestico_Service tree. In: E. Bellini editor. Le specie legnose da frutto. Liste dei caratteri descrittivi. Firenze: Arsia, (2002), pp. 815-827.

[3] C. Bignami, Il sorbo. Proceedings of Progetto GENRES 29 “Conservazione dei fruttiferi minori”. Firenze 27-28 November, 1998 , p. 18.

[4] C. Bignami, Il sorbo domestico. L'informatore agrario 34 (2000), 55-58.

[5] C. Bignami, G. Bertazza, M. Paolacci and M. Petricca, Caratteristiche qualitative di pomacee minori. In: S. Pandolfi, M.V. Parlati, F. Libori editors. Proceedings of V Giornate scientifiche. Trevi (Italy): Studio mmagine s.a.s., 2002, pp. 281-282.

[6] W. Brand-Williams, M.E. Cuvelier and C. Berset, Use of a free radical method to evaluate antioxidant activity, Food Sci Technol 28 (1995), 25-30.

[7] J. Blažek and J. Hlušićková, Seed count fruit quality and storage properties in four apple cultivars, J Fruit Ornam Plant Res 14 (2006), $151-160$.

[8] J. Brindza, J. Červeňáková, D. Tóth, D. Bíro and J. Sajbidor, Unutilized potential of true service tree (Sorbus domestica L), Acta Hort (ISHS) 806 (2009), 717-772.

[9] M. Buccheri and C. Di Vaio, Relationship among seed number quality and calcium content in apple fruits, J Plant Nut 27 (2004), $1735-1745$.

[10] I. Egea, P. Sánchez-Bel, F. Romojaro and M.T. Pretel, Six edible wild fruits as potential antioxidant additives or nutritional supplements, Plant Foods Hum Nutr 65 (2010), 121-129.

[11] D. Huang, B. Ou and R.L. Prior, The chemistry behind antioxidant capacity assays, Journal of Agricoltural and Food Chemistry 53 (2005), 1841-1856.

[12] L.K. Macdonald-Wicks, L.G. Wood and M.L. Garg, Methodology for the determination of biological antioxidant capacity in vitro: A review, J Sci Food Agri 86 (2006), 2046-2056.

[13] M. Olszewska, Separation of quercetin sexangularetin kaempferol and isorhamnetin for simultaneous HPLC determination of flavonoid aglycones in inflorescens leaves and fruits of three Sorbus species, J Pharm Biomed Anal 48 (2008), 629-635.

[14] A. Termentzi, P. Kefalas and E. Kokkalou, Antioxidant activities of various extracts and fractions of Sorbus domestica fruits at different maturity stages, Food Chem 98 (2006), 599-608.

[15] A. Termentzi, P. Alexiou, V.J. Demopoulos and E. Kokkalou, The aldose reductase inhibitory capacity of Sorbus domestica fruit extracts depends on their phenolic content and may be useful for the control of diabetic complications, Pharmazie 63 (2008), 693-696.

[16] A. Termentzi, P. Kefalas and E. Kokkalou, LC-DAD-MS (ESI+) analysis of the phenolic content of Sorbus domestica fruits in relation to their maturity stage, Food Chem 106 (2008), 1234-1245.

[17] J. Turok, G. Erickson, J. Kleinschmit and S. Canger, Eds., Noble Hardwoods Network. Report of the First Meeting held in Escherode, International Plant Genetic Resources Institute, Rome, Germany, 1996.

[18] J. Turok, E. Collin, B. Demesure, G. Erickson, J. Kleinschmidt, M. Rusanen and R. Stephan, Eds., Noble Hardwoods Network. Report of the Second Meeting held in Lourizán, International Plant Genetic Resources Institute, Rome, Spain, 1997.

[19] J. Turok, J. Jensen, C. Palmberg-Lerche, M. Rusanen, K. Russel, S. de Vries and E. Lipman, Eds., Noble Hardwoods Network. Report of the Third Meeting held in Sagadi, International Plant Genetic Resources Institute, Rome, Estonia, 1998.

[20] U. Vrhovsek, A. Rigo, D. Tonon and F. Mattivi, Quantitation of polyphenols in different apple varieties, J Agr Food Chem 52 (2004), 6532-6538.

[21] PG. Waterman and S Mole, Analysis of Phenolic Plant Metabolites. In: J.H. Lawton and G.E. Likens editors. Methods in ecology. Oxford: Blackwell Scientific Publications. (1994), pp. 1-238.

[22] H. Wolf, Conservation and breeding of wild fruit tree species in forestry, Acta Hort (ISHS) 538 (2000), 57-56.

[23] Y. Zou, Y. Lu and D. Wei, Antioxidant activity of a flavonoid-rich extract of Hypericum perforatum L in vitro, J Agr Food Chem 52 (2004), $5032-5039$. 